\title{
The Influence of Age and Size on Family-Owned Firms' Financing Decisions: Empirical Evidence Using Panel Data
}

\author{
Zélia Serrasqueiro, Paulo Maçãs Nunes, Jacinto Vidigal da Silva
}

Based on four samples of Portuguese family-owned firms - i) 185 young, low-sized family-owned firms; ii) 167 young, high-sized familyowned firms; iii) 301 old, low-sized family-owned firms; and iv) 353 old, high-sized family-owned firms - we show that age and size are fundamental characteristics in family-owned firms' financing decisions. The multiple empirical evidence obtained allows us to conclude that the financing decisions of young, low-sized family-owned firms are quite close to the assumptions of Pecking Order Theory, whereas those of old, high-sized family-owned firms are quite close to what is forecast by Trade-Off Theory. The lesser information asymmetry associated with greater age, the lesser likelihood of bankruptcy associated with greater size, as well as the lesser concentration of ownership and management consequence of greater age and size, may be especially important in the financing decisions of family-owned firms. In addition, we find that GDP, interest rate and periods of crisis have a greater effect on the debt of young, low-sized family-owned firms than on that of family-owned firms of the remainder research samples.

\section{Introduction}

In the context of firms' financing decisions, following the important studies by Modigliani and Miller (1958, 1963), ascertaining what the main determinants of these financial decisions were became the focus of various studies. Thus, two theories are particularly important in explaining firms' financial decisions: i) Trade-Off Theory (Kim, 1978; Kraus and Litzenberger, 1973; Scott, 1977), and ii) Pecking Order Theory (Myers, 1984; Myers and Majluf, 1984). According to TradeOff Theory, firms seek to reach an optimal level of debt, which implies balancing the benefits and costs of debt. According to Pecking Order Theory, variations in debt do not seek to reach an optimal level of debt but are the consequence of external financing needs, because when internal funds are insufficient, firms prefer to turn to debt rather than external equity.

The main objective of family-owned firms is to keep ownership in family hands, which leads to the reluctance to acquire external financing, with these firms having a clear preference for internal financing (Blanco-Mazagatos et al., 2010).

Hannan and Freeman (1984) state that firms' age and size may be particularly relevant for strategic options of firms. Furthermore, Hannan (1998) claims that organizations' initial situation - namely the quality and quantity of the resources - affects their future strategies and survival. As financial resources are fundamental to firms' activity, age and size may be crucial factors in explaining firms' financing decisions; we can expect the financing decisions of young, small firms to be quite different from those of older, larger ones.

When internal financing is insufficient, difficulties in accessing external financing are one of the main limitations to growth in European firms (Jöeveer, 2012). On the one hand, the dependence on internal financing diminishes with increased firm size, since greater size generally implies less likelihood of bankruptcy, greater transparency of information provided about firm size, and greater capacity to provide collaterals (Berger and Udell, 1998; Diamond, 1991), allowing large firms access to debt on more advantageous terms. On the other hand, higher firm age involves great reputation and less uncertainty about the future, also contributing to older firms gaining easier access to debt (Chittenden et al., 1996; Diamond, 1989; Hall et al., 2004).

Family-owned firms are especially relevant in the economies of developed countries, as they stimulate employment and economic growth (Eklund et al., 2013; Poutziouris, 2001; Uhlaner et al., 2012). Given the importance of these firms in the economies of developed countries, the study of how they finance their activities is also very relevant, since obstacles in accessing finance may affect their growth and survival options. Greater age and greater size are important characteristics of the firms for then obtain financing on favorable terms, so influencing their funding decisions (Ang, 1991; Berger and Udell, 